\title{
Penerapan Model Discovery Learning untuk Meningkatkan Aktivitas Belajar SDN 10 Koto Tinggi
}

\author{
Rike Kartika Sari ${ }^{1}$, Nikmat Elva $^{1}$, Cici Sumiati ${ }^{3}$ \\ ${ }^{1}$ Program Pendidikan Profesi Guru, Universitas Negeri Padang \\ ${ }^{3}$ SD Negeri 20 Indarung, Padang, Indonesia \\ e-mail :rikekartika28@gmail.com¹, ninitoke64@gmail.com², cici.sumiati@gmail.com³
}

\begin{abstract}
Abstrak
Penelitian ini mengkaji aktivitas belajar siswa dalam proses belajar. Tujuan penelitian adalah untuk meningkatkan aktivitas belajar siswa dengan menerapkan model pembelajaran discovery learning. Metode penelitian adalah Penelitian Tindakan Kelas (PTK) yang dilaksanakan dalam 2 siklus dengan tahapan setiap siklus yaitu perencanaan, pelaksanaan, pengamatan, dan refleksi.Teknik pengumpulan data berupa teknik non tes.Alat pengumpul data menggunakan lembar observasi.Teknik analisis data menggunakan teknik analisis kualitatif dan analisis kuantitatif.Hasil penelitian menunjukkan bahwa penerapan model discovery learning dapat meningkatkan aktivitas belajar siswa.
\end{abstract}

Kata kunci: Model Discovery Learning Dan Aktivitas Belajar.

\begin{abstract}
This study examines student learning activities in the learning process. The purposes of research were to improve learning activity by implementation discovery learning model. The method of research was classroom action research implemented in two cycles that consist of planning, action, observation, and reflection. Data were collected by non test. The instrument of data collection used observation sheet. The tecniques The result of research showed that implementation discovery learning model can improve student learning activity.
\end{abstract}

Keywords: discovery learning model, and learning activity.

\section{PENDAHULUAN}

Pendidikan merupakan suatu sentral utama berkualitasnya suatu negara, dengan berkualitas pendidikan di suatu negara maka kualitas sumber daya manusia yang ada pada negara tersebut akan baik.Pada hakikatnya, pendidikan bertujuan untuk memanusiakan manusia dan mengembangkan potensi yang ada dalam diri manusia itu sendiri. Melalui pendidikan suatu bangsa dapat menjadi suatu bangsa yang tangguh, mandiri, berkarakter, dan berdaya saing.

Pendidikan sebagai wadah untuk meningkatkan aktivitas sumber daya manusia membutuhkan guru yang menjadi ujung tombak dalam mencerdaskan kehidupan bangsa. Kehadiran guru mutlak diperlukan dalam proses pendidikan. Sebagaimana diketahui, inti dari proses pendidikan adalah proses pembelajaran. Proses pembelajaran merupakan bagian dari pengelolaan pembelajaran dan guru menjadi penentu keberhasilan pembelajaran yang akan dilaksanakan. Pengelolaan pembelajaran yang dimulai dari tahap perencanaan, pelaksanaan, evaluasi dan tindak lanjut membutuhkan kepiawaian seorang guru. Guru begitu berpengaruh terhadap keberhasilan pendidikan sehingga guru memegang peranan yang sangat penting dalam usaha mencerdaskan kehidupan bangsa.

Guru yang profesional merupakan faktor penentu proses pendidikan yang berkualitas. Menurut Tabrani dalam Aqib (2013: 72), salah satu kemampuan dasar yang harus dimiliki guru profesional adalah kemampuan mengelola pembelajaran. Guru harus dapat 
menciptakan suasana pembelajaran yang kondusif dan membuat pembelajaran menjadi efektif.

Selain guru, pengelolaan pembelajaran tentu turut menentukan keberhasilan suatu pendidikan. Untuk mendukung keberhasilan suatu proses pembelajaran, diperlukan model pembelajaran yang dapat meningkatkan keatifan peserta didik dalam belajar agar pembelajaran menjadi bermakna. Pembelajaran yang bermakna diperoleh dari keterlibatan peserta didik secara aktif dalam pembelajaran. Menurut Rusman (2010: 257), pembelajaran tematik mengarahkan peserta didik secara aktif terlibat dalam proses pembelajaran. Pembelajaran tematik menyajikan berbagai mata pelajaran ke dalam tema-tema.Melalui pembelajaran tematik, peserta didik dapat memperoleh pengalaman langsung dan terlatih untuk dapat menemukan sendiri pengetahuan yang dipelajari secara utuh dan bermakna.Pembelajaran tematik membutuhkan model pembelajaran yang memfasilitasi peserta didik untuk dapat terlibat secara aktif dalam pembelajaran agar peserta didik memperoleh pengalaman belajar yang bermakna.Model pembelajaran secara tidak langsung memfasilitasi peserta didik memperoleh seperangkat sikap, pengetahuan, dan keterampilan dalam pembelajaran.

Berdasarkan pengamatan yang dilakukan oleh peneliti pada bulan Januari 2021, pembelajaran yang dilakukan di SD Negeri 10 Kototinggi berlangsung dengan kegiatan ceramah dan tanya jawab. Kondisi ini membuat keaktifan peserta didik tidak merata. Hanya peserta didik tertentu yang menyimak dengan baik, dalam proses pembelajaran dapat juga dilihat hanya peserta didik yang ditanya saja yang aktif. Tak beberapa lama, banyak peserta didik asyik dengan kesibukannya sendiri seperti mengobrol dan tidak memperhatikan penjelasan dari guru.Hanya beberapa peserta didik saja yang masih memperhatikan penjelasan dari guru.Sebagian besar peserta didik kurang menunjukkan antusias selama pembelajaran berlangsung.Ada sebagian peserta didik yang asyik bermain dengan alat tulisnya dan ada juga peserta didik yang menyanyi sendiri.Peserta didik cenderung kurang bersemangat dengan materi pembelajaran dan cenderung terlihat bosan.Kondisi ini membuat keaktifan peserta didik tidak merata dan akhirnya berdampak pada hasil belajar peserta didik. Untuk lebih jelasnya data disajikan sebagai berikut.

Selaras dengan hal di atas, berdasarkan hasil observasi diperoleh data bahwa dari 11 orang siswa hanya $27,27 \%$ yang aktif sedangkan $72,73 \%$ berada pada kategori cukup aktif, kurang aktif, dan tidak aktif. Sebagaimana yang dijelaskan Mulyasa (2013: 131) suatu pembelajaran dikatakan berhasil apabila terjadi perubahan perilaku yang positif pada diri siswa seluruhnya atau setidak-tidaknya sebagian besar $(75 \%)$ dari seluruh siswa di kelas dapat mencapai tujuan pembelajaran dengan kategori aktif.

Berdasarkan uraian di atas perlu diadakan perbaikan dan perubahan dalam proses pembelajaran agar aktivitas belajar siswa dapat ditingkatkan dan mencapai hasil yang maksimal. Banyak model pembelajaran yang dapat dipilih dan digunakan oleh guru dalam pembelajaran , salah satunya discovery learning.

Menurut Susanto (2013: 18) menyatakan bahwa secara metodologis, aktivitas belajar lebih dominan pada siswa.Pada dasarnya, segala sesuatu yang diamati, dilakukan sendiri dan terlibat aktif terhadap interaksi yang terjadi pada suatu objek yang akan menghasilkan sebuah pengalaman yang berkesan dan memberikan kontribusi yang sangat besar terhadap kebermaknaan aktivitas yang akan ditimbulkan.Selanjutnya, Suryosubroto dalam Jurotun (2015) mendefinisikan Discovery Learning sebagai sebuah prosedur mengajar yang mementingkan pembelajaran, perseorangan, manipulasi objek dan lain-lain percobaan, sebelum sampai kepada sebuah penarikan kesimpulan. Maka dalam Discovery Learning guru tidak menjelaskan dengan kata-kata mengenai pengertian, sebelum siswa sadar akan pengertian tersebut.

Model ini mendorong peserta didikuntuk menemukan sendiri dan mentransformasikan informasi kompleks, mengecek informasi baru dengan yang sudah ada dalam ingatannya, dan melakukan pengembangan menjadi informasi atau kemampuan yang sesuai dengan lingkungan dan zaman, tempat, dan waktu ia hidup. Peserta didikadalah subjek yang memiliki kemampuan untuk secara aktif mencari, mengolah, mengonstruksi, dan menggunakan 
pengetahuan. Untuk itu, pembelajaran harus berkenaan dengan kesempatan yang diberikan kepada peserta didikuntuk mengonstruksi pengetahuan dalam proses kognitifnya (Hosnan, 2014: 282).

Menurut Syah (2014:244) dalam mengaplikasikan Discovery Learningdi kelas, ada beberapa prosedur yang harus dilaksanakan dalam kegiatan belajar mengajar secara umum yaitu

1. Stimulation (Stimulasi/Pemberian rangsangan)

Pertama-tama pada tahap ini peserta didik dihadapkan pada sesuatu yang menimbulkantanda tanya, kemudian dilanjutkan untuk tidak memberi generalisasi, agar timbul keinginan untuk menyelidiki sendiri. Disamping itu pendidik dapat memulai kegiatan KBM dengan mengajukan pertanyaan, anjuran membaca buku, dan aktivitas belajar lainnya yang mengarah pada persiapan pemecahan masalah.

2. Problem statement (Pernyataan/Identifikasi masalah)

Setelah dilakukan stimulasi langkah selanjutya adalah pendidik memberi kesempatan kepada peserta didik untuk mengidentifikasi sebanyak mungkin agenda-agenda masalah yang relevan dengan bahan pelajaran, kemudian salah satunya dipilih dan dirumuskan dalam bentuk hipotesis (jawaban sementara atas pertanyaan masalah).

3. Data collection (Pengumpulan Data)

Ketika eksplorasi berlangsung guru juga memberi kesempatan kepada para peserta didik untuk mengumpulkan informasi sebanyak-banyaknya yang relevan untuk membuktikan benar atau tidaknya hipotesis. Pada tahap ini berfungsi untuk menjawab pertanyaan atau membuktikan benar tidaknya hipotesis. Dengan demikian anak didik diberi kesempatan untuk mengumpulkan (collection) berbagai informasi yang relevan, membaca literatur, mengamati objek, wawancara dengan narasumber, melakukan ujicoba sendiri dan sebagainya.

4. Data Processing (Pengolahan Data)

Semua informai hasil bacaan, wawancara, observasi, dan sebagainya, semuanya diolah, diacak, diklasifikasikan, ditabulasi, bahkan bila perlu dihitung dengan cara tertentu serta ditafsirkan pada tingkatkepercayaan tertentu.

5. Verification (Pembuktian)

Pada tahap ini siswa melakukan pemeriksaan secara cermat untuk membuktikan benar atau tidaknya hipotesis yang ditetapkan tadi dengan temuan alternatif, dihubungkan dengan hasil data processing.

6. Generalization (Menarik kesimpulan/Generalisasi)

Tahap generalisasi/menarik kesimpulan adalah proses menarik sebuah kesimpulan yang dapat dijadikan prinsip umum dan berlaku untuk semua kejadian atau masalah yang sama dengan memperhatikan hasil verifikasi.

Menurut Hosnan (2014:287-288) Kelebihan model Discovery Learning yaitu (1) membantu peserta didik untuk memperbaiki dan meningkatkan keterampilan-keterampilan dan proses-proses kognitif, (2) pengetahuan yang diperoleh melalui metode ini sangat pribadi dan ampuh karena menguatkan pengertian, ingatan dan transfer,(3) dapat meningkatkan kemampuan siswa untuk memecahkan masalah (4) membantu peserta didik memperkuat konsep dirinya karena memperoleh kepercayaan bekerjasama dengan oranglain, (5) mendorong keterlibatan keaktifan peserta didik,(6) mendorong peserta didik untuk berfikir intuisi dan merumuskan hipotesis sendiri, dan (7) melatih peserta didik belajar mandiri. Sedangkan menurut Kurniasih \& Sani (2014:66-67) yaitu (1) Menimbulkan rasa senang pada peserta didik, karena tumbuhnya rasa menyelidiki dan berhasil. (2)Peserta didik akan mengerti konsep dasar dan ide-ide lebih baik. (3) Mendorong peserta didik berfikir dan bekerja atas inisiatif sendiri. (4) Peserta didik belajar dengan memanfaatkan berbagai jenis sumber belajar

Berdasarkan uraian di atas, maka penelitian ini bertujuan untuk meningkatkan aktivitas belajar siswa kelas II SD Negeri 10 Kototinggi melalui penggunaan model discovery learning.

\section{METODE}


Metode penelitian ini menggunakan penelitian tindakan kelas (clasroom action research).Prosedur penelitian yang digunakan berbentuk siklus, yang berlangsung selama dua siklus.Setiap siklus terdiri dari empat tahapan, yaitu perencanaan, pelaksanaan, pengamatan, dan refleksi (Wardhani, 2007: 2.3). Subjek dari penelitian tindakan kelas ini adalah guru dan siswa kelas II SD Negeri 10 Kototinggi Tahun Pelajaran 2020/2021 dengan jumlah siswa dalam kelas tersebut adalah 11 orang siswa, yang terdiri atas 5 orang siswa lakilaki dan 6 orang siswa perempuan. Penelitian tindakan kelas ini dilaksanakan pada semester genap tahun pelajaran 2020/2021.Teknik pengumpulan data menggunakan teknik non tes.Alat pengumpul data menggunakan lembar observasi.Lembar observasi digunakan untuk mengamati kinerja guru dan aktivitas belajar siswa.Data yang diperoleh dianalisis menggunakan teknik analisis kualitatif dan analisis kuantitatif.

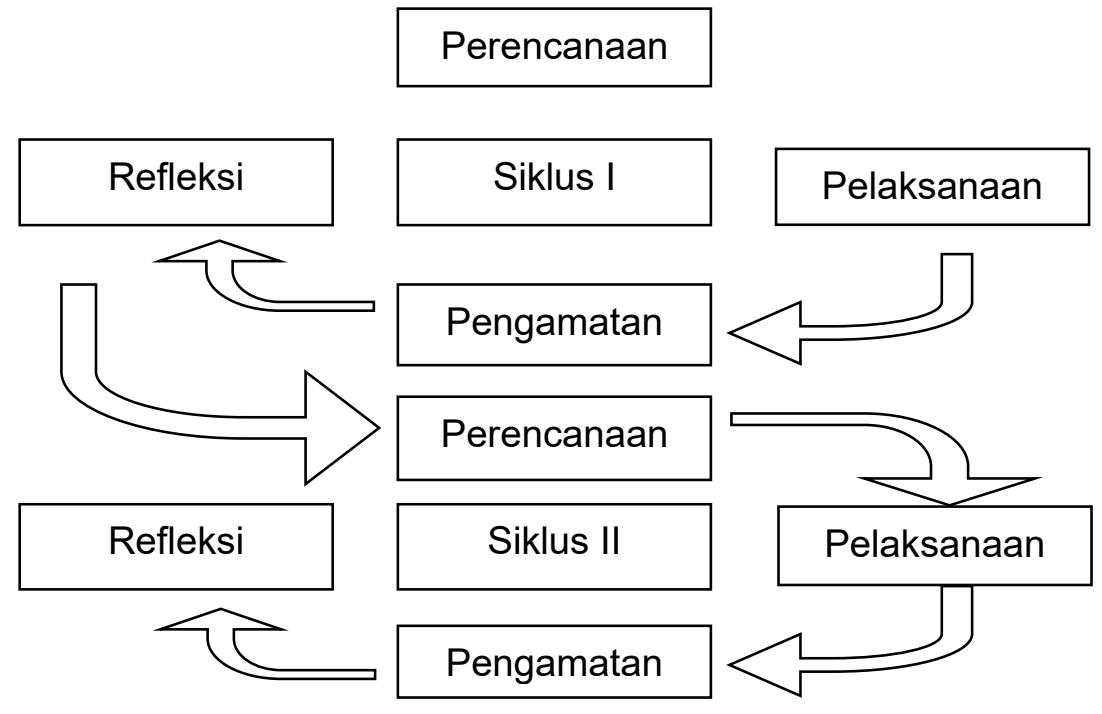

Gambar 1 Alur siklus penelitian tindakan kelas

\section{HASIL DAN PEMBAHASAN}

Penelitian ini dilaksanakan di kelas II SD Negeri 10 Kototinggi, Kecamatan Suliki, Kabupaten Lima Puluh Kota pada semester genap tahun pelajaran 2020/2021.Terdapat dua siklus dalam penelitian ini, setiap siklus terdiri dari dua pertemuan. Penelitian siklus I dilaksanakan pada hari Selasa tanggal 20April 2021 pukul 08.30 sampai 11.30 WIB, Kamis tanggal 22 April 2021 pukul 08.30 sampai 11.30 WIB. Siklus II dilaksanakan pada hari Selasa tanggal 4 Mei 2021 pukul 08.30 sampai 11.30 WIB, Kamis tanggal 6 Mei 2021 pukul 08.30 sampai 11.30 WIB.

Prosedur penelitian dalam penelitian tindakan kelas ini, sebagai berikut.

1. Perencanaan, yakni menyusun apa saja yang akan dilakukan dalampelaksanaan penelitian tindakan kelas.

2. Tindakan, yakni pelaksanaan penelitian tindakan kelas.

3. Observasi,yakni pengamatan selama pelaksanaan tindakan.

4. Refleksi,yakni evaluasi hasil pelaksanaan tindakan.

Hasil penelitian menunjukkan terdapat peningkatan kinerja guru dan aktivitas belajar siswa dari siklus I ke siklus II sebagai berikut.

Tabel 1 Rekapitulasi nilai kinerja guru siklus I dan II. 


\begin{tabular}{|l|l|c|c|c|}
\hline No & \multicolumn{1}{|c|}{ Kinerja Guru } & Siklus I & Siklus II & Peningkatan \\
\hline 1 & Jumlah rata-rata skor & 107,5 & 118,5 & 11,00 \\
\hline 2 & Nilai & 76,78 & 84,64 & 7,86 \\
\hline
\end{tabular}

Agar lebih jelas mengenai perubahan dan peningkatan kinerja guru dalam proses pembelajaran, dapat dilihat pada grafik berikut.

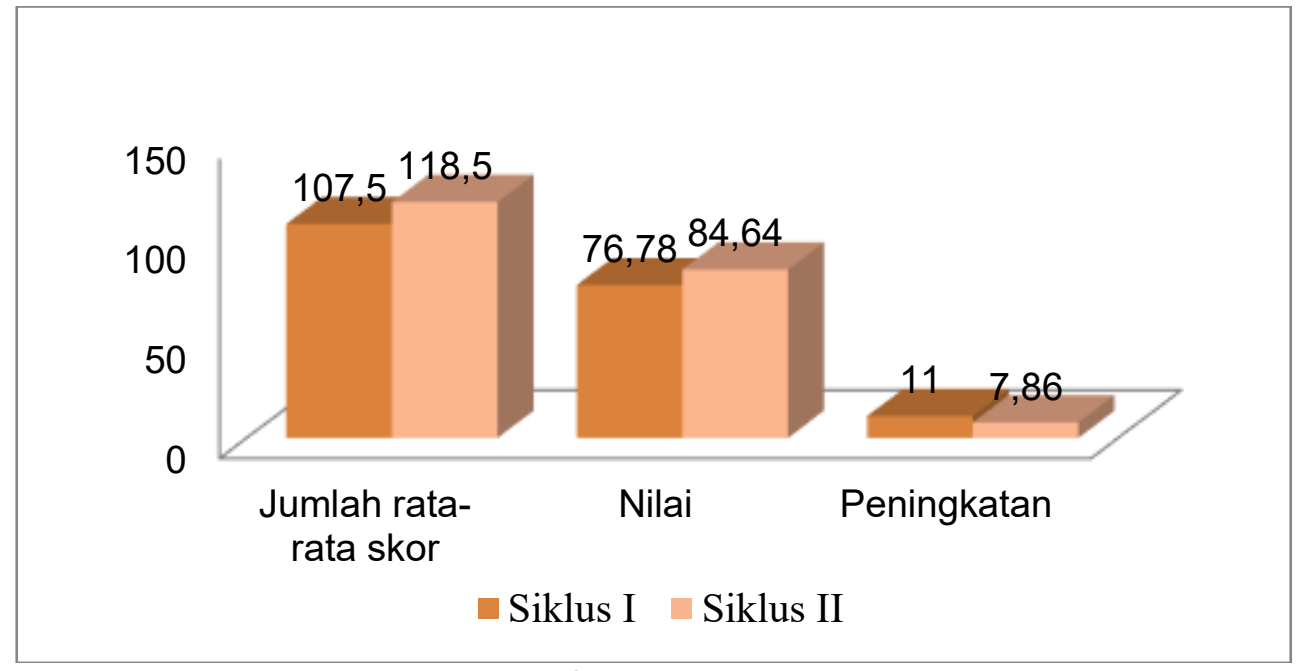

\section{Kinerja Guru}

\section{Gambar 2 Grafik kinerja guru dalam menerapkan model discovery learning}

Berdasarkan tabel 1 dan gambar 2dapat diketahui bahwa data kinerja guruselama proses pembelajaran siklus I diperoleh rata-rata skor 107,5 dengan nilai 76,78 , pada siklus II diperoleh rata-rata skor 118,5 dengan nilai 84,64 . Peningkatan jumlah rata-rata skor kinerja guru siklus I ke II adalah 11,00. Sedangkan Peningkatan nilai kinerja guru dari siklus I ke siklus II adalah 7,86. Hal tersebut di dukung oleh Rusman (2011: 80) bahwa keterampilan mengajar guru merupakan sautu karakteristik umum dari seseorang yang berhubungan dengan pengetahuan dan keterampilan yang diwujudkan melalui tindakan.

Tabel.2 Rekapitulasi hasil aktivitas belajar Siswa

\begin{tabular}{|l|l|c|c|c|}
\hline No & Aktivitas Belajar Siswa & Siklus I & Siklus II & Peningkatan \\
\hline 1 & Rata-rata jumlah siswa Sangat aktif \& aktif & 7 & 9,5 & 2,50 \\
\hline 2 & Persentase siswa Sangat aktif \& aktif & 63,62 & 86,35 & 22,73 \\
\hline 3 & Kategori & Cukup Aktif & Sangat Aktif & \\
\hline
\end{tabular}

Agar lebih jelas mengenai perubahan dan peningkatan aktivitas belajar siswa dalam proses pembelajaran, dapat dilihat pada grafik berikut. 


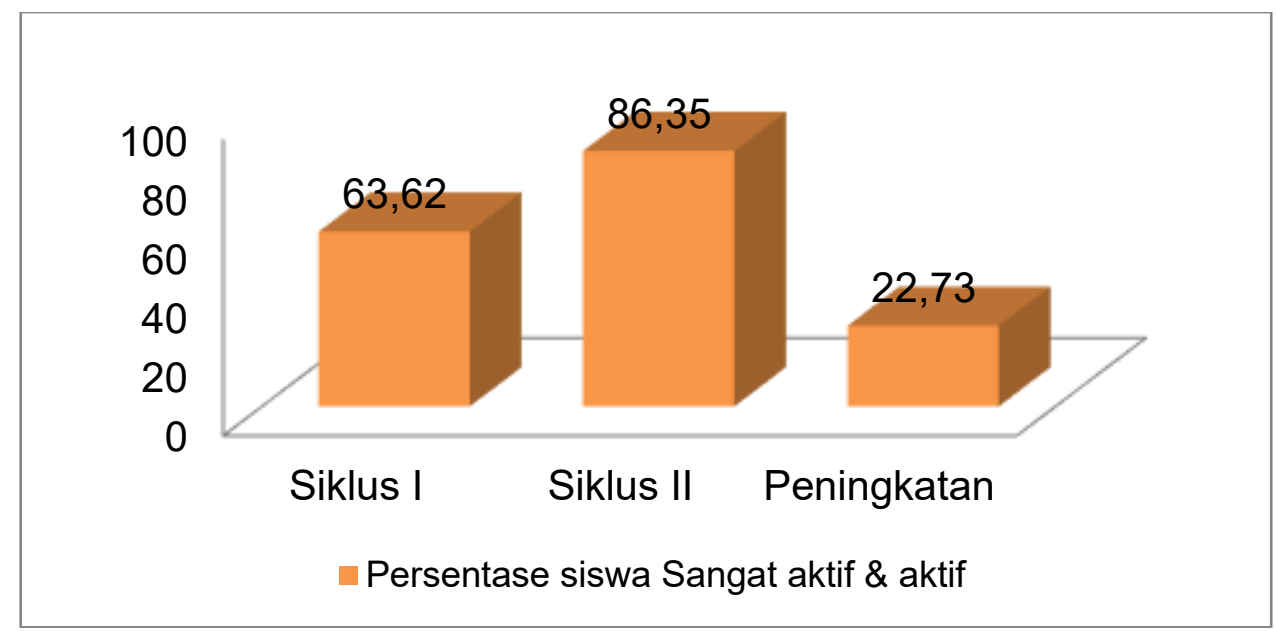

Aktivitas Belajar Siswa

\section{Gambar 3 Grafik persentase aktvitas belajar siswa}

Berdasarkan tabel2 dan gambar 3 dapat diketahui aktivitas siswa dengan kategori sangat aktif dan aktif pada siklus I sebesar $63,62 \%$, pada siklus II sebesar $86,35 \%$ dengan peningkatan persentase aktivitas siswa pada siklus I ke siklus II yaitu $22,73 \%$. Hal tersebut membuktikan bahwa persentase aktivitas belajar siswa telah mencapai indikator keberhasilan yang di tentukan.Oleh karena itu, kegiatan observasi aktivitas belajar siswa diberhentikan sampai dengan siklus II.

\section{SIMPULAN}

Berdasarkan hasil penelitian tindakan kelas yang telah dilaksanakan melalui penerapan model pembelajaran discovery learning pada pembelajaran untuk meningkatkan aktivitas belajar siswa SD Negeri 10 Kototinggi dapat disimpulkan bahwa adanya peningkatan aktivitas belajar siswa, hal ini dibuktikan dengan aktivitas belajar pada siklus I sebesar $63,62 \%$, pada siklus II sebesar $86,35 \%$ dengan peningkatan persentase aktivitas belajar siswa pada siklus I ke siklus II yaitu $22,73 \%$. Pada siklus I jumlah rata-rata siswa dengan kategori sangat aktif dan aktif yaitu 7 siswa. Sedangkan pada siklus II terdapat 9,5 siswa, dengan peningkatan siklus I ke siklus II sebanyak 2,5 siswa.

Dari hasil yang diperoleh peneliti berdasarkan dari apa yang telah diungkapkan sebelumnya, maka dapat menjawab hipotesis penelitian ini, yaitu penerapan model discovery learning dapat meningkatkan aktivitas belajar siswa kelas II SD Negeri 10 Kototinggi Tahun Pelajaran 2020/2021.

\section{DAFTAR RUJUKAN}

Aqib, Zainal, dkk. 2010. Penelitian Tindakan Kelas (PTK) untuk Guru SD, SLB, TK. Yrama Widya Bandung.

Hosnan.2014. Pendekatan Saintifik dan Kontekstual dalam Pembelajaran Abad 21.Ghalia Indonesia: Bogor.

Jurotun. 2015. Meningkatkan Komunikasi Matematis Peserta Didik melalui Discovery Lerning Berbantuan Software Geogebra. Jurnal Kreano. 6 (1): 1-6. http://journal.unnes.ac.id/nju/index.php/kreano

Kurniasih, Imas \& Berlin Sani. 2014. Implementasi Kurikulum 2013 Konsep dan Penerapan.Kata Pena: Surabaya.

Rusman. 2011. Model-model Pembelajaran. Raja Grafindo Persada. Jakarta.

Susanto, Ahmad. 2013. Teori Belajar dan Pembelajaran di Sekolah Dasar. Prenadamedia Group. Jakarta.

Syah, Muhibbin. 2014. Psikologi Belajar. Rajawali Pers: Jakarta. 